DOI: http://dx.doi.org/10.33846/hn50304

http://heanoti.com/index.php/hn

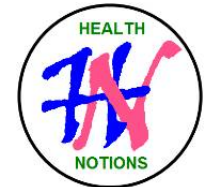

RESEARCH ARTICLE

URL of this article: http://heanoti.com/index.php/hn/article/view/hn50304

\title{
Profile of Muscle Strength and Physical Performance with the Incidence of Urinary
} Incontinence in Elderly Women

\begin{tabular}{c} 
Jihan Nabila Pranjasdhina ${ }^{\mathbf{1 ( C A})}$, Novira Widajanti ${ }^{2}$, Rwahita Satyawati Dharmanta \\
${ }^{\mathbf{3}}$ \\
1(CA) Faculty of Medicine, Univeritas Airlangga, Indonesia; pranjasbela@ @mail.com (Corresponding Author) \\
${ }^{2}$ Department of Internal Medicine, Faculty Medicine, Universitas Airlangga, Indonesia \\
${ }^{3}$ Departement of Physical Medicine and Rehabilitation, Faculty of Medicine, Universitas Airlangga, Indonesia \\
\hline
\end{tabular}

\section{ABSTRACT}

Introduction: The 200 million people in the world experience urinary incontinence. In general, with increasing age, the capacity of the bladder decreases. The remaining urine in the bladder tends to increase and irregular contraction of the bladder muscles becomes more frequent. This situation often makes the elderly experience problems with the fulfillment of urine elimination needs, namely urinary incontinence. Efforts to overcome urinary incontinence in the form of bladder training programs are aimed at developing muscle tone and bladder sphincter so that it can function optimally. Objective: Knowing the profile of muscle strength and physical performance with the incidence of urinary incontinence in elderly women. Methods: This research was a retrospective descriptive study based on the results of filling out the questionnaire and evaluating it directly. Based on tabulated data, 38 elderly women were selected as the study sample. Results: There were $(42.1 \%)$ urinary incontinence on elderly with very poor left hand muscle strength and $(50 \%)$ urinary incontinence on elderly with very poor right hand muscle strength. In physical performance with urinary incontinence as many as $(57.8 \%)$ were normal and $(42.1 \%)$ were poor. Conclusions: Muscle strength and physical performance can be used as a measurement to early detection of the urinary incontinence.

Keywords: urinary incontinence; muscle strength; physical performance; descriptive retrospective study

\section{Background}

\section{INTRODUCTION}

Urinary incontinence (UI) is a common health problem, in elderly population especially elderly women Urinary incontinence is common in elderly women ${ }^{(1)}$. One of the complaints that is often experienced by the elderly due to the aging process is urinary incontinence, where urinary incontinence is a decrease in capacity and reduced ability of striated muscle resistance in the urethra due to physiological changes in the elderly. The occurrence of the aging process that causes a decrease in many organ systems including decreased muscle strength and physical performance which increases the risk of falls, fractures, decreased quality of life, and death. According to data from WHO, 200 million people in the world experience urinary incontinence. In the United States, the number of people with incontinence reaches 13 million, with 85 percent of them being women. In Indonesia, around 5.8\% of Indonesia's population suffer from urinary incontinence ${ }^{(2)}$. Even though the prevalence of UI is relatively high, only some patients are concerned about their complaints. they don't even think of the UI as a burden.

Aging is an advanced stage of life in a life process ${ }^{(3)}$. Physiologically, the aging process is a gradual and regular decline of an organ or organ system and a decrease in homeostatic control. With increasing age, various decreases in function occur in old age. Decreased function, especially Activity Daily Living (ADL), can cause various problems in the elderly, one of which is the involuntary leaked of urine which is known as urinary incontinence. It not only causes physical problems but UI also causes psychological, social, economic problems as well as the patient's quality of life ${ }^{(4)}$.

In general, with increasing age, the capacity of the bladder decreases. The remaining urine in the bladder tends to increase and irregular contraction of the bladder muscles becomes more frequent. This situation often makes the elderly experience problems with the fulfillment of urine elimination needs, namely urinary incontinence. Efforts to overcome urinary incontinence in the form of bladder training programs are aimed at developing muscle tone and bladder sphincter so that it can function optimally ${ }^{(5)}$.

\section{Purpose}

The purpose of this studi is knowing the profile of muscle strength and physical performance with the incidence of urinary incontinence in elderly women. 


\section{METHODS}

This descriptive retrospective study had been approved by Health Research Ethics Committee Universitas Airlangga school of Medicine, Surabaya through ethical clearance (252/EC/KEPK/FKUA/2020). This research was conducted at Tambak Rejo Surabaya Health Center, precisely at Jalan Ngaglik No. 87, Tambakrejo, Simokerto District, Surabaya City, East Java.

This research was conducted in August-November 2019. The sample and population of this study were elderly women at Tambakrejo Surabaya Public Health Center who were female and met the inclusion and exclusion criteria. Inclusion criteria were women, age $\geq 60$ years, GCS 456 and participating in the study by signing the research informed consent sheet; and exclusion criteria, namely using a wheelchair or assistive device to walk, severe depression (GDS>10), history of uterine malignancy, experiencing cognitive impairment (MMSE> 18). This research was a descriptive retrospective study based on the results of filling out the questionnaire and evaluating it directly at the Tambak Rejo Health Center, Surabaya. The variables in this study were age, muscle strength, physical performance, uterine malignancy, urinary incontinence. In this study an evaluation of the profile of elderly women was recorded by recording age, muscle strength, physical performance by looking at walking, cognitive status, depressive status and uterine malignancy status. After processing the data, data will be obtained in the form of ordinal data. Then the data were analyzed descriptively.

\section{The Characteristics of Respondents}

\section{RESULTS}

The results of the study were to determine the characteristics of the research subjects at Tambak Rejo Public Health Center, Surabaya, which obtained the mean for age in elderly women 67 years. Meanwhile, for the assessment of depression status using the Geriatric Depression Scale (GDS) questionnaire divided into normal with a score of 0-4, most likely depression with a score of 5-9, indicating depression with a score of $>10$. Based on the results of the assessment of the research subjects, it was obtained GDS with a mean of 2 which was included in the normal category. Then to see the scoring of the cognitive assessment using Mini Mental State Examination (MMSE) divided into normal with a score of 24-30, probable cognitive impairment with a score of 17-23, and definitive cognitive impairment with a score of 0-16. Based on the results of research at Tambak Rejo Health Center, Surabaya MMSE with a mean of 24 which means normal and no results were obtained on uterine malignancy.

Table 1. Description of the characteristics

\begin{tabular}{ccc}
\hline Variable & Mean & Std. deviation \\
\hline Age & 67 & 5.90254 \\
GDS & 2 & 2.0000 \\
MMSE & 24 & 4.87511 \\
Uterine malignancy & 0 & 0.0000 \\
\hline
\end{tabular}

\section{Distribution of Muscle Strength by Hand Grip Strength}

Muscle strength distribution data obtained from handgrip strength measurements. Left handgrip strength measurement was classified with very good of $\geq 37 \mathrm{~kg}$, good $27 \mathrm{~kg}-36.5 \mathrm{~kg}$, moderate $19 \mathrm{~kg}-26.5 \mathrm{~kg}$, poor $14 \mathrm{~kg}-$ $18.5 \mathrm{~kg}$ and very poor at $\leq 13.5$. The distributions are presented in the table below.

Table 2. Distribution of left handgrip strength

\begin{tabular}{ccc}
\hline Variable & Frequency & Percent \\
\hline Very Good & 0 & 0 \\
Good & 0 & 0 \\
Moderate & 6 & 15.8 \\
Poor & 9 & 23.7 \\
Very Poor & 23 & 60.5 \\
\hline
\end{tabular}

The results of the research for left hand muscle strength, which was conducted at the Tambak Rejo Public Health Center, Surabaya showed that the percentage of $15.8 \%$ was obtained for moderate muscle strength, $23.7 \%$ for poor muscle strength, $60.5 \%$ for very poor muscle strength.

Muscle strength distribution data obtained from handgrip strength measurements. Right handgrip strength measurement was classified with very good of $\geq 42.5 \mathrm{~kg}$, good $32.5 \mathrm{~kg}-41 \mathrm{~kg}$, moderate $24.5 \mathrm{~kg}-32 \mathrm{~kg}$, poor $18.5 \mathrm{~kg}$ $24 \mathrm{~kg}$, very poor $\leq 18 \mathrm{~kg}$.

Table 3. Distribution of right handgrip strength

\begin{tabular}{ccc}
\hline Variable & Frequency & Percent \\
\hline Very Good & 0 & 0 \\
Good & 0 & 0 \\
Moderate & 0 & 0 \\
Poor & 10 & 26.3 \\
Very Poor & 28 & 73.7 \\
\hline
\end{tabular}

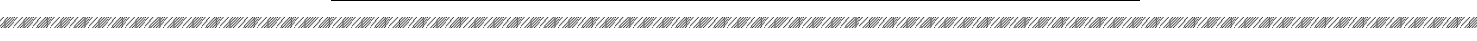
92 Publisher: Humanistic Network for Science and Technology 
The results of the research for right hand muscle strength, which was conducted at the Tambak Rejo Public Health Center, Surabaya showed that the percentage of $26.3 \%$ for poor muscle strength, $73.7 \%$ for very poor muscle strength.

\section{Distribution of Physical Performance}

Physical performance distribution data from the measurement of $6 \mathrm{~m}$ usual gait speed with a cutoff value of $0.8 \mathrm{~m} / \mathrm{s}$. The distributions are presented in the table below.

Table 4. Distribution of physical performance

\begin{tabular}{ccc}
\hline Variable & Frequency & Percent \\
\hline Normal & 22 & 57.9 \\
Poor & 16 & 42.1 \\
\hline
\end{tabular}

From the research data at Tambak Rejo Health Center, Surabaya, it was found that $57 \%$ had normal physical performance and $42.1 \%$ with poor physical performance.

\section{Distribution of Urinary Incontinence with (International Consultation on Incontinence Questionnaire) ICIQ UI}

Researchers looked for demographic characteristics in research subjects, namely elderly women (over 60 years) based on an assessment of urinary incontinence using the ICIQ UI questionnaire and identified them according to the predetermined classification, namely mild urinary incontinence with a score of 1-6, mild to moderate urinary incontinence. with a score of 7-12, moderate urinary incontinence with a score of 13-18, severe urinary incontinence with a score of 19-24 and very severe urinary incontinence with a score of 25-30.

Table 5. Distribution of urinary incontinence

\begin{tabular}{ccc}
\hline Variable & Frequency & Percent \\
\hline No UI & 12 & 31.6 \\
Mild UI & 19 & 50.0 \\
mild-moderate UI & 5 & 13.2 \\
moderate UI & 2 & 5.3 \\
Severe UI & 0 & 0 \\
Very Severe UI & 0 & 0 \\
\hline Total & 38 & 100.00
\end{tabular}

From the research data at Tambak Rejo Health Center, Surabaya, the results are based on the above categories, it turns out that elderly women at Tambak Rejo Health Center with no urinary incontinence was $31.6 \%$, mild urinary incontinence by $50 \%$, mild to moderate UI was $13.2 \%$ and moderate UI was $5.3 \%$. That the total who experienced urinary incontinence, both mild urinary incontinence, mild-moderate urinary incontinence, moderate urinary incontinence was $68.5 \%$, so it was much higher than those who didn't experience urinary incontinence

\section{Profiles Hand Grip with Urinary Incontinence}

Based on the results of research conducted regarding the measurement of the left hand handgrip with the incidence of urinary incontinence, the results are obtained according to the table below:

Table 6. Distribution of left handgrip measurements with incidence of urinary incontinence

\begin{tabular}{ccccccc}
\hline & & \multicolumn{3}{c}{ ICIQ UI } & \multirow{2}{*}{ Total } \\
\cline { 3 - 5 } & & NO UI & Mild UI & UI mild -moderate & Moderate UI & \\
\hline \multirow{3}{*}{ Left Handgrip } & Very good & $0.0 \%$ & $0.0 \%$ & $0.0 \%$ & $0.0 \%$ & $0.0 \%$ \\
strength & Good & $0.0 \%$ & $0.0 \%$ & $0.0 \%$ & $0.0 \%$ & $0.0 \%$ \\
& Moderate & $2.6 \%$ & $7.9 \%$ & $5.3 \%$ & $0.0 \%$ & $15.8 \%$ \\
& Poor & $10.5 \%$ & $7.9 \%$ & $5.3 \%$ & $0.0 \%$ & $23.7 \%$ \\
& Very Poor & $18.4 \%$ & $34.2 \%$ & $2.6 \%$ & $5.3 \%$ & $60,5 \%$ \\
\hline
\end{tabular}

From the table above, it is found that those with moderate left hand grip muscle strength and no urinary incontinence was $2.6 \%$, with mild urinary incontinence was $7.9 \%$ and mild-moderate urinary incontinence was $5.3 \%$. The left handgrip muscle strength with poor muscle strength and no urinary incontinence was $10.5 \%$, mild urinary incontinence was $7.9 \%$ and mild-moderate urinary incontinence was $5.3 \%$. lastly left handgrip with very poor muscle strength with no urinary incontinence was $18.4 \%$, experienced mild urinary incontinence was $34.2 \%$, mild-moderate urinary incontinence was $2.6 \%$ and $5.3 \%$ for those who have moderate urinary incontinence.

From the table above, it is found that those with poor right hand grip strength and no urinary incontinence was $37.9 \%$, mild urinary incontinence was $7.9 \%$, mild-moderate urinary incontinence was $10.5 \%$ and results for moderate urinary incontinence. Very poor right handgrip muscle strength with nourinary 
incontinence was $23.7 \%$, mild urinary incontinence was $42.1 \%$, mild-moderate urinary incontinence was $2.6 \%$, and moderate urinary incontinence was $5.3 \%$.

Table 7. Distribution of right handgrip measurements with incidence of urinary incontinence

\begin{tabular}{ccccccc}
\hline & & \multicolumn{3}{c}{ ICIQ UI } & \multirow{2}{*}{ Total } \\
\cline { 3 - 6 } & & NO UI & Mild UI & UI mild -moderate & Moderate UI & \\
\hline \multirow{3}{*}{ Left Handgrip } & Very good & $0.0 \%$ & $0.0 \%$ & $0.0 \%$ & $0.0 \%$ & $0.0 \%$ \\
strength & Good & $0.0 \%$ & $0.0 \%$ & $0.0 \%$ & $0.0 \%$ & $0.0 \%$ \\
& Moderate & $0.0 \%$ & $0.0 \%$ & $0.0 \%$ & $0.0 \%$ & $0.0 \%$ \\
& Poor & $7.9 \%$ & $7.9 \%$ & $10.5 \%$ & $0.0 \%$ & $26.3 \%$ \\
& Very Poor & $23.7 \%$ & $42.1 \%$ & $2.6 \%$ & $5.3 \%$ & $73.7 \%$ \\
\hline
\end{tabular}

\section{Physical Performance Profile (6m Usual Gait Speed) with Urinary Incontinence}

Based on the results of research conducted regarding the measurement of physical performance with the incidence of urinary incontinence, the results are obtained according to the table below:

Table 8. Distribution of physical performance with urinary incontinence

\begin{tabular}{ccccccc}
\hline & & \multicolumn{3}{c}{ ICIQ UI } & \multirow{2}{*}{ Total } \\
\cline { 2 - 6 } & & NO UI & Mild UI & UI mild -moderate & Moderate UI & $5.3 \%$ \\
\hline \multirow{2}{*}{$6 \mathrm{~m}$ usual gait speed $(\mathrm{m} / \mathrm{s})$} & Normal & $21.1 \%$ & $26.3 \%$ & $5.3 \%$ & $5 \%$ \\
\cline { 2 - 7 } & Less & $10.5 \%$ & $23.7 \%$ & $7.9 \%$ & $0.0 \%$ & $42.1 \%$ \\
\hline
\end{tabular}

Based on the table above, the results of poor physical performance was $7.9 \%$ with mild-moderate urinary incontinence, $23.7 \%$ with mild urinary incontinence, and $10.5 \%$ without urinary incontinence. Whereas in people with normal physical performance, $5.3 \%$ had moderate urinary incontinence, $5.3 \%$ had mild-moderate urinary incontinence, $26.3 \%$ had mild urinary incontinence and $21.1 \%$ had no urinary incontinence.

\section{DISCUSSION}

Based on the results of research conducted at Tambak Rejo Public Health Center, Surabaya, 23 people with very poor muscle strength, including 13 people experiencing mild urinary incontinence, 1 person with mild-moderate urinary incontinence, 2 people experiencing moderate urinary incontinence, and 7 people with no urinary incontinence. In cases of very poor muscle strength, the incidence of urinary incontinence increased even though only mild, mild-moderate urinary incontinence had occurred, and some had moderate urinary incontinence. For the classification of poor muscle strength there are 9 people, 3 of them had mild urinary incontinence, 2 of them had mild-moderate urinary incontinence, and none had moderate urinary incontinence, and 4 of them did not experience urinary incontinence. Six people had moderate muscle strength including 1 person who did not experience urinary incontinence, 3 people had mild urinary incontinence, and 2 people had moderate urinary incontinence.

Meanwhile, on the right handgrip measurement, it is suspected that a person will lose about $20-40 \%$ of his skeletal muscle mass and strength from the age of 20-80 years. Low skeletal muscle mass is associated with low strength, decreased lower limb performance, functional impairment, falls, and physical disabilities. Hand grip strength correlates strongly with other tests of muscle strength and is thus often considered to represent whole-body muscle strength. In this study, there were 28 people with very low muscle strength, including 16 people experiencing mild urinary incontinence, 1 person with mild-moderate urinary incontinence, 2 people experiencing moderate urinary incontinence, and 9 people experiencing no incontinence. For the classification of muscle strength as many as 10 people, of which 3 people experienced mild urinary incontinence, 4 people experienced mild-moderate urinary incontinence, and none had moderate urinary incontinence, and 3 people did not experience urinary incontinence. From the research results, it can be seen that there is a relationship between urinary incontinence and hand muscle strength in the elderly at Tambakrejo Health Center. Same as previous research which states that there is a strong relationship between urinary incontinence and musculoskeletal disorders including muscle strength. Weakness in muscle strength can cause a variety of symptoms that interfere with quality of life ${ }^{(5)}$. So, in this study, it was found that in elderly women who had a right handgrip assessment, the results of the incidence of urinary incontinence were getting bigger, both mild-moderate urinary incontinence, mild urinary incontinence, and moderate urinary incontinence. So that education will be given to the public, especially research subjects, that the results of this study can provide information, namely weakness in muscle strength and the effect of physical performance is one of the parameters that must be considered because it can cause disturbances in the lower urinary tract and urinary muscle muscles which will aggravate urinary incontinence. in old age.

Based on the results of a study on the incidence of urinary incontinence with an assessment of physical performance at the Tambak Rejo Public Health Center, Surabaya, the results were for normal physical performance with 2 people experiencing moderate urinary incontinence, 2 people experiencing mild-moderate 
urinary incontinence, 10 people experiencing mild urinary incontinence, and 8 people don't have urinary incontinence. For poor physical performance, moderate urinary incontinence was not obtained, 3 people experienced mild-moderate urinary incontinence, 9 people experienced mild urinary incontinence, and 4 people did not experience urinary incontinence. The decline in cognitive function is generally experienced by the elderly as a result of the aging process ${ }^{(6)}$. The impact of this decline in cognitive function will cause limitations in carrying out functional activities. So it is possible that when measuring the physical performance of the elderly they have a low cognitive status or experience depression, so that the physical performance assessment is not carried out as optimally as possible ${ }^{(7)}$. In this study, it was found that in elderly women who had a poor physical performance assessment, the incidence of urinary incontinence was also reduced, both mild-moderate urinary incontinence, mild urinary incontinence, and moderate urinary incontinence. Given the requirements for handgrip measurement, it requires good mood and cognitive ability to get maximum results. So that in this study, it is possible that those who experience urinary incontinence actually have good muscle strength and physical performance, but at that time there is a depression disorder, both probable and definitive.

\section{CONCLUSION}

In this study, it was found that in elderly women who had a left handgrip assessment, the results of the incidence of urinary incontinence were getting bigger, both mild to moderate urinary incontinence, mild urinary incontinence, and moderate urinary incontinence. There is a strong relationship between urinary incontinence and musculoskeletal disorders including muscle strength. From the research results, it can be seen that there is a relationship between urinary incontinence and hand muscle strength in the elderly.

Whereas in physical performance, poor physical performance are less then normal physical performance in elderly women at Tambak Rejo Health Center, Surabaya. Which may be caused by decreased cognitive function or experiencing depression, resulting in the assessment of physical performance which results in limitations in carrying out functional activities.

\section{REFERENCES}

1. Darmojo B, Martono H. Buku ajar geriatri (ilmu kesehatan usia lanjut). Jakarta: Balai Pustaka FKUI; 2006.

2. Maas ML, Buckwalter KC, Hardy MD, Tripp-Reimer T, Titler MG, Specht JP. Asuhan Keperawatan Geriatric, Diagnosis Nanda, Kriteria Hasil Noc, Intervensi Nic. Jakarta: EGC; 2011.

3. Smith MD, Russell A, Hodges PW. Disorders of breathing and continence have a stronger association with back pain than obesity and physical activity. Aust J Physiother. 2006;52:11-6.

4. Jansen. Hubungan status fungsional dengan inkontinensia urin pada usia lanjut di griya usia lanjut Santo Yosef Surabaya. 2017.

5. Cao JJ, Kurimoto P, Boudignon B, Rosen C, Lima F, Halloran BP. Aging impairs IGF-I receptor activation and induces skeletal resistance to IGF-I. J Bone Miner Res. 2007;22(8):1271-9.

6. Cao JJ, Wronski TJ, Iwaniec U, Phleger L, Kurimoto P, Boudignon B, et al. Aging increases stromal/osteoblastic cell-induced osteoclastogenesis and alters the osteoclast precursor pool in the mouse. $\mathrm{J}$ Bone Miner Res. 2005;20(9):1659-68.

7. Chahal HS, Drake WM. The endocrine system and ageing. Journal of Pathology. 2007.211(2):173-80. 